\title{
Carbon indices to assess quality of management systems in a Subtropical Acrisol
}

\author{
Josiléia Acordi Zanatta ${ }^{\oplus}$, Frederico Costa Beber Vieira ${ }^{2} \odot$, Clever Briedis ${ }^{3 *} \oplus$, Jeferson Dieckow ${ }^{4 \oplus}$, Cimélio Bayer ${ }^{5}$
}

${ }^{1}$ Embrapa Florestas, Estrada da Ribeira, km 111 - 83411000 - Colombo, PR - Brasil.

2Universidade Federal do Pampa, Av. Antônio Trilha, 1847 97300-000 - São Gabriel, RS - Brasil.

${ }^{3}$ Embrapa Instrumentação, R. XV de Novembro, 1452 13560-970 - São Carlos, SP - Brasil.

4Universidade Federal do Paraná - Depto. de Solos e Engenharia Agrícola, R. dos Funcionários, 1540 - 80035050 - Curitiba, PR - Brasil.

5Universidade Federal do Rio Grande do Sul/Faculdade de Agronomia - Depto. de Solos, Av. Bento Gonçalves, 7712 91540-000 - Porto Alegre, RS - Brazil.

*Corresponding author <cleverbriedis@yahoo.com.br>

Edited by: Eduardo Alvarez Santos

Received September 07, 2017

Accepted May 21, 2018
ABSTRACT: Management systems to improve soil quality are essential for agricultural and environmental sustainability. We assessed the quality of soil management systems applied to a subtropical Acrisol in terms of the carbon management index (CMI), the stratification ratio for total organic carbon (SR-TOC) and light fraction of organic matter (SR-LF). In addition, we examined their relationship to chemical, physical and biological soil quality indicators, as well as to maize yield. The study was conducted on a long-term experiment (18 years) in southern Brazil involving two different systems [no tillage (NT) and conventional tillage (CT)], two cropping systems [black oat/maize $(\mathrm{O} / \mathrm{M})$ and black oat + vetch/maize + cowpea $(\mathrm{OV} / \mathrm{MC})]$ and two nitrogen fertilizer rates for maize $\left(0\right.$ and $\left.180 \mathrm{~kg} \mathrm{ha}^{-1}\right)$. Based on the three indices, the best managements for soil quality comprised NT (50-212 \% better than CT), legume cover crops ( $10-47 \%$ better than $0 / \mathrm{M}$ ) and $\mathrm{N}$ fertilization (8-33 \% better than no fertilizer). All three indices proved accurate to assess the impact of soil management systems, especially SR-LF, which showed increased sensitivity and close relationships with chemical, physical and biological soil quality indicators. On the other hand, a poor relationship was observed between soil $\mathrm{C}$ indices and maize yield, which was improved only by legume cover crops and $\mathrm{N}$ fertilization. The results showed that the association of no-till system to an abundant supply of crop residues is key to ensure high soil quality and crop yields in humid subtropical regions.

Keywords: conservation agriculture, cropping systems, no-till, quality indicators

\section{Introduction}

Conventional tillage $(\mathrm{CT})$ has contributed to a faster decline of original soil carbon (C) stocks, thereby having an adverse impact on soil and environment quality mainly in tropical and subtropical regions (Houghton, 2014; Lal, 2004). Thus, the high soil degradation rates contrast with the target of agriculture to feed a population increase of $45 \%$ until the end of the century (Gerland et al., 2014).

Conservation management systems such as no-tillage (NT) promote soil C accumulation by keeping a less oxidative environment (Bayer et al., 2000; Sá et al., 2015; Tivet et al., 2013). Furthermore, C accumulation under NT system is usually higher in crop rotations involving legume cover crops (Boddey et al., 2010; Conceição et al., 2013; Zanatta et al., 2007), also improving biological, physical and chemical soil attributes and crop yields (Conceição et al., 2005).

In order to predict the quality of soil management systems in an integrated approach, Blair et al. (1995) proposed the carbon management index (CMI), which combines $\mathrm{C}$ quantity and lability. Since then, the CMI index has successfully been used to assess soil quality in management systems in subtropical and tropical regions (Diekow et al., 2005; Souza et al., 2014). Furthermore, the $\mathrm{C}$ stratification ratio (SR), which is the $\mathrm{C}$ content ratio between surface and subsurface soil layers (Franzluebbers, 2002), has also been used as a useful indicator of soil quality. Several studies have reported a high SR with improvements in soil quality indicators under conservation management systems (Franzluebbers, 2002; Franzluebbers, 2010; Sá and Lal, 2009).
The primary objectives of this study were to assess the quality of management systems in terms of CMI, SR of total and labile C. Therefore, we examined the sensitivity of these indices to management practices and their relationship with physical, chemical and biological soil quality indicators in a subtropical Acrisol subjected to different management regimes for over 18 years. The hypotheses were that (i) NT in combination with an increased supply of plant residues including legume cover crops and/or nitrogen fertilizer results in higher $\mathrm{C}$ indices; and (ii) indices based on labile SOM fractions are more sensitive to management practices and have a closer relationship with chemical, physical and biological soil quality indicators, as well as with maize yield.

\section{Materials and Methods}

\section{Site description}

This study was based on a long-term field experiment (18 years) conducted in southern Brazil $\left(30^{\circ} 50^{\prime} \mathrm{S}\right.$, $51^{\circ} 38^{\prime} \mathrm{W}, 46 \mathrm{~m}$ asl), a region with a subtropical climate (Cfa, according to Köppen), with an average annual temperature of $19.4{ }^{\circ} \mathrm{C}$ and average annual rainfall of 1440 $\mathrm{mm}$. The soil is a sandy clay loam Acrisol, according to the FAO classification system (Argissolo Vermelho by Brazilian System or Typic Paleudult by Soil Taxonomy), with $220 \mathrm{~g}$ clay kg-1 and $540 \mathrm{~g}^{-1}$ sand $\mathrm{kg}^{-1}$ in the $0-20 \mathrm{~cm}$ layer.

Prior to the experiment, the field was a natural grassland (mainly Paspalum spp. and Andropogon spp.), which was converted into cropland in 1969 and cultivated using conventional tillage with plowing, disking and rotary hoe for 16 years. This management regime led to 
a significant physical degradation of the soil (Bayer et al., 2000 ) as it was observed in 1985, when the experiment was started.

\section{Treatments and experimental design}

The experiment included two soil tillage systems, arranged in main plots of $15 \times 20 \mathrm{~m}$ : conventional tillage (CT) and no-tillage (NT). Each tillage system was composed of two cropping systems in subplots of $5 \times 20$ $\mathrm{m}$ : black oats (Avena strigosa Schreb)/maize (Zea mays L.) (O/M) and oats + vetch (Vicia sativa L.)/maize + cowpea (Vigna unguiculata (L.) Wald) (OV/MC). Two fertilization levels, 0 and $180 \mathrm{~kg} \mathrm{ha}^{-1}$ of $\mathrm{N}$-urea (0N and $180 \mathrm{~N}$ ), were applied in strips in the maize crop, characterizing the subsubplots $(5 \times 10 \mathrm{~m})$. The experimental design consisted of randomized blocks with split-split plots and three replications.

Winter crops were established in Apr-May of each year. In the end of the cycle of winter cover crops in spring, tillage systems were applied. The CT plots were ploughed to a furrow-depth of $17 \mathrm{~cm}$ using a three-disk plow and harrowed twice to a depth of $10 \mathrm{~cm}$ using a disk harrow mixing the crops residues in this layer. At the same time, glyphosate-based herbicide was applied in the NT plots at $1.4 \mathrm{~kg} \mathrm{ha}^{-1}$ according to final glyphosate concentration. Two or three days later the winter cover crops were managed with a knife-roller and aboveground residues were left on the soil surface. Maize was sown in Sept-Oct and irrigated by sprinkler. The fertilizer rate applied in maize was 21.5 and $41.5 \mathrm{~kg} \mathrm{ha}^{-1}$ of $\mathrm{P}$ and $\mathrm{K}$ (50 and $50 \mathrm{~kg} \mathrm{ha}^{-1}$ of $\mathrm{P}_{2} \mathrm{O}_{5}$ and $\mathrm{K}_{2} \mathrm{O}$ ), respectively. Cowpea was manually sown some days after maize, between the crop rows, in pits located $40 \mathrm{~cm}$ apart. After maize was harvested, cowpea developed fully, remaining until mechanical management to allow establishment of oats and vetch.

\section{Soil sampling}

After 18 years of experiment and prior to tillage operations in CT in Oct 2003, the soil was sampled by hand, using a spatula at depths 0-2.5, 2.5-5, 5-10 and $10-20 \mathrm{~cm}$. Two subsamples from each plot were composited. Soil samples from the neighboring native grassland were also collected and used as reference for the original soil conditions, before soil degradation. Samples were air-dried, sieved through a $2 \mathrm{~mm}$ mesh and stored in plastic pots.

\section{Addition of $\mathbf{C}$ to the soil}

The average annual addition of $\mathrm{C}$ via crop biomass was estimated from dry matter (DM) data for cover crops and maize grain yield over the 18-year experimental period (Table 1). Dry matter of the cover crop was measured in a $1-\mathrm{m}^{2}$ area in each plot. Maize DM input was calculated with provision for grain yield and the harvest index of Lovato et al. (2004). C contents of plant residues were all assumed at $40 \%$ (Bayer et al., 2000) and roots DM was equivalent to $30 \%$ of shoot DM, as estimated by Zanatta et al. (2007) based on the scientific literature.
Table 1 - Average amount of annual carbon (C) input by cover crops plus maize over the 18-year experimental period.

\begin{tabular}{|c|c|c|c|}
\hline \multirow{2}{*}{ Cropping system² } & \multirow{2}{*}{$\mathrm{N}$ rate } & \multicolumn{2}{|c|}{ Soil tillage $^{1}$} \\
\hline & & CT & NT \\
\hline & $\mathrm{kg} \mathrm{ha}^{-1}$ & \multicolumn{2}{|c|}{$\mathrm{C}$ added (Mg ha-1) } \\
\hline \multirow[t]{2}{*}{ O/M } & 0 & $4.1 \pm 0.8^{3}$ & $4.0 \pm 0.7$ \\
\hline & 180 & $6.3 \pm 1.3$ & $6.4 \pm 1.5$ \\
\hline \multirow[t]{2}{*}{$\mathrm{OV} / \mathrm{MC}$} & 0 & $7.6 \pm 1.8$ & $7.6 \pm 1.6$ \\
\hline & 180 & $8.7 \pm 1.9$ & $8.7 \pm 1.9$ \\
\hline
\end{tabular}

${ }^{1} \mathrm{CT}=$ conventional tillage; NT = no-tillage. ${ }^{2} \mathrm{O} / \mathrm{M}=$ oat $/ \mathrm{maize} ; \mathrm{OV} / \mathrm{MC}=$ oat + vetch/maize + cowpea. ${ }^{3}$ Mean \pm standard deviation.

\section{Density fractionation and carbon analysis}

Soil organic matter of samples was physically fractionated using a NaI solution under sonication. Briefly, a 20 -g soil sample previously sieved through a $2 \mathrm{~mm}$ mesh was added to a $100-\mathrm{mL}$ centrifuge tube containing 80 $\mathrm{mL}$ of $\mathrm{NaI}$ solution $\left(1.8 \mathrm{~g} \mathrm{~cm}^{-3}\right)$. The resulting suspension was sonicated at $250 \mathrm{~J} \mathrm{~mL}^{-1}$ to ensure a complete disruption of soil organo-mineral complexes. Prior to weighing, the suspension was centrifuged at $2000 \mathrm{~g}$ for $30 \mathrm{~min}$ and the supernatant vacuum-filtered through fiberglass of $1.2 \mu \mathrm{m}$ pore size, which was previously oven-dried at $50{ }^{\circ} \mathrm{C}$. The material retained on the filter was rinsed with distilled water to remove salts to have OM particulate and light fraction (LF) labeled. The filter containing $\mathrm{LF}$ was oven-dried at $50{ }^{\circ} \mathrm{C}$, weighed and ground in an agate mortar.

C contents of whole soil and LF samples were determined by dry combustion at $900{ }^{\circ} \mathrm{C}$ on a Shimadzu VCHS TOC analyzer. Respective C stocks were calculated with provision for the soil bulk density and layer thickness as corrected with the soil equivalent mass approach (Ellert and Bettany, 1995), using the mass of soil layers in the native grassland as reference. Soil bulk density was determined at the $16^{\text {th }}$ year of the experiment (Silva et al., 2005). The C stock of the heavy fraction $(\mathrm{HF})$ was calculated as the difference between the total organic $\mathrm{C}$ stock and the LF C stock.

\section{Carbon management index and carbon stratification ratio}

The carbon management index (CMI) for 0-20 $\mathrm{cm}$ layer was calculated as originally proposed by Blair et al. (1995), and LF and HF were used as proxies for the labile and non-labile $\mathrm{C}$ pool, respectively (Vieira et al., 2007). CMI was calculated based on the native grassland soil used as reference (CMI = 100), as follows:

$\mathrm{CMI}=\mathrm{CPI} \times \mathrm{CLI} \times 100$

$\mathrm{CPI}=\mathrm{C}$ pool index $=$ treatment $\mathrm{C}$ stock/reference $\mathrm{C}$ stock

$\mathrm{CLI}=\mathrm{C}$ lability index $=$ treatment C lability $(\mathrm{L}) /$ reference C lability 
$\mathrm{L}=\mathrm{C}$ stock in labile fraction $(\mathrm{LF}) / \mathrm{C}$ stock in non-labile fraction $(\mathrm{HF})$

The stratification ratio (SR) for total organic C (SRTOC) and the light fraction of organic matter (SR-LF) were calculated as the ratio of $C$ contents in $0-5 \mathrm{~cm}$ and 5-20 cm layer, respectively (Franzluebbers, 2002).

\section{Soil quality indicators and maize yield}

The impact of management systems on physical, chemical and biological soil quality indicators, and on maize yield, and their relationship with $\mathrm{C}$ indices (CMI and SR), was assessed from historical data for the experimental area (Table 2). We considered five crop seasons (2001-2005) rather than a single one to determine maize yield to ensure more consistent results and minimize the potential impact of climate and agricultural practices during the years.

\section{Statistical analysis}

The data of $\mathrm{C}$ contents and stocks of whole soil and LF, CMI, SR-TOC and SR-LF were evaluated by the analysis of variance (ANOVA) and significant $F$-values. The differences between treatment means were evaluated by the Tukey test $(p<0.05)$. We established linear regressions of annual $\mathrm{C}$ addition as crop biomass and CPI, CLI, CMI, SR-TOC and SR-LF, and of CMI, SR-TOC and SR-LF with chemical, physical and biological soil quality indicators, as well as maize yield. All statistical computations were performed using software $\mathrm{R}$, version 3.1.1.

\section{Results and Discussion}

\section{Carbon management index and its components}

Changes in $\mathrm{C}$ content caused by the management systems relative to the native vegetation (Table 3) were joined by similar variations in the $\mathrm{C}$ pool index (CPI)
(Table 4). In the 0-20 cm layer, organic C stocks ranged from 27.8 to $39.5 \mathrm{Mg} \mathrm{ha}^{-1}$, and CPIs from 0.62 to 0.88 , across management systems. CPI was $14 \%$ higher on average under NT than under $\mathrm{CT}$, possibly because of the less oxidative environment and the physical protection of SOM provided by NT (Tivet et al., 2013).

Cropping systems also affected CPI. The system based on legume cover crops (OV/MC) increased CPI by $17 \%$ on average compared to the system based only on grass (O/M, Table 4). The increased CPI for the legumebased system was attributed to an increased supply of $\mathrm{C}$ to the soil via crop residues (Figure 1A). This result reflects the favorable effect of legume cover crops by increasing the net primary productivity of the whole cropping system and promoting $\mathrm{C}$ accumulation in this subtropical soil (Boddey et al., 2010; Conceição et al., 2013; Zanatta et al., 2007).

$\mathrm{N}$ fertilization also increased the CPI in all management systems, however, to a lesser extent than the inclusion of legumes in rotation did (Table 4). The appli-

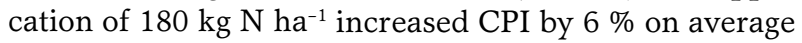
in the tillage and cropping systems (i.e., much less than the $17 \%$ increase obtained with legumes). This lesser effect was probably because fertilizer- $\mathrm{N}$ was more prone to losses through leaching and volatilization, as it was less effective to promote $\mathrm{C}$ accumulation than legume- $\mathrm{N}$ was, which was combined with $\mathrm{C}$ in organic structures in biomass residue and mineralized more synchronically with $\mathrm{N}$ uptake by maize crop (Qiu et al., 2016).

C stocks in LF in $0-20 \mathrm{~cm}$ layer ranged from 1.06 to $2.91 \mathrm{Mg} \mathrm{ha}^{-1}$ (Table 3 ) and stored 4 to $7 \%$ of total organic C. Carbon lability index (CLI) was higher under NT than under CT and was directly related to the annual supply of $\mathrm{C}$ by the crops, which was higher in legume-based and in $\mathrm{N}$ fertilization systems (Figure 1B). While the effect of cropping system and $\mathrm{N}$ fertilization is more closely related to the annual supply of added plant residues, the effect of $\mathrm{NT}$ on $\mathrm{C}$ lability is linked to a less

Table 2 - Biological [microbial biomass (C-MBC), carbon dioxide evolution $\left(\mathrm{C}-\mathrm{CO}_{2}\right.$ ) and potentially mineralizable nitrogen (PMN)], physical [aggregate stability (AS)] and chemical [cation exchange capacity (CEC)] soil quality indicators, and maize yield, in a subtropical Acrisol subjected to two tillage systems, two cropping systems and two $\mathrm{N}$ fertilization rates.

\begin{tabular}{|c|c|c|c|c|c|c|c|c|}
\hline Soil tillage $^{1}$ & Cropping system ${ }^{2}$ & $\mathrm{~N}$ rate & C-MBC 3 & $\mathrm{C}-\mathrm{CO}_{2}{ }^{3}$ & $\mathrm{PMN}^{3}$ & $A S^{4}$ & CEC & Maize yield ${ }^{5}$ \\
\hline & & $\mathrm{kg} \mathrm{ha}^{-1}$ & $-n$ & $s^{-1}$ & $\mathrm{~kg} \mathrm{ha}^{-1}$ & $\%$ & $\mathrm{cmol}_{\mathrm{c}} \mathrm{kg}^{-1}$ & Mg ha-1 \\
\hline \multirow[t]{4}{*}{ CT } & $0 / M$ & 0 & $116 \pm 4^{6}$ & $87 \pm 61$ & $6.0 \pm 1.7$ & $52 \pm 5$ & $10.3 \pm 0.3$ & $2.66 \pm 1.21$ \\
\hline & & 180 & $129 \pm 11$ & $132 \pm 52$ & $9.5 \pm 2.8$ & $63 \pm 10$ & $10.1 \pm 0.1$ & $8.86 \pm 1.57$ \\
\hline & $\mathrm{OV} / \mathrm{MC}$ & 0 & - & - & - & - & $10.0 \pm 0.2$ & $3.66 \pm 1.29$ \\
\hline & & 180 & - & - & - & - & $10.1 \pm 0.1$ & $9.17 \pm 1.44$ \\
\hline \multirow[t]{4}{*}{ NT } & $0 / M$ & 0 & - & - & - & - & $10.5 \pm 0.1$ & $2.30 \pm 1.05$ \\
\hline & & 180 & $210 \pm 11$ & $277 \pm 105$ & $13.8 \pm 2.8$ & $87 \pm 7$ & $10.8 \pm 0.7$ & $8.98 \pm 1.16$ \\
\hline & $\mathrm{OV} / \mathrm{MC}$ & 0 & - & - & - & - & $11.1 \pm 0.6$ & $4.49 \pm 1.50$ \\
\hline & & 180 & $240 \pm 8$ & $322 \pm 138$ & $20.5 \pm 7.5$ & $88 \pm 5$ & $10.8 \pm 0.3$ & $9.55 \pm 1.89$ \\
\hline
\end{tabular}

${ }^{1} \mathrm{CT}=$ conventional tillage; NT = no-tillage; ${ }^{2} \mathrm{O} / \mathrm{M}=$ oat/maize; OV/MC = oat + vetch/maize + cowpea. ${ }^{3}$ Data from Conceição et al. (2005). ${ }^{4}$ Data from Amado et al. (2007). ${ }^{5}$ Average of five crop seasons (i.e., 2001-2005). ${ }^{6}$ Mean \pm standard deviation. 
Table 3 - Organic carbon content and stock in whole soil and in the light fraction of a subtropical Acrisol subjected to two tillage systems, two cropping systems and two $\mathrm{N}$ fertilization rates for 18 years.

\begin{tabular}{|c|c|c|c|c|c|c|c|}
\hline \multirow{2}{*}{ Soil tillage ${ }^{1}$} & \multirow{2}{*}{ Cropping system ${ }^{2}$} & \multirow{2}{*}{$\begin{array}{l}\text { N rate } \\
\left(\mathrm{kg} \mathrm{ha}^{-1}\right)\end{array}$} & \multicolumn{5}{|c|}{ Layer $(\mathrm{cm})$} \\
\hline & & & $0-2.5$ & $2.5-5$ & $5-10$ & $10-20$ & $0-20$ \\
\hline & & & \multicolumn{4}{|c|}{$\longrightarrow \mathrm{g} \mathrm{kg}^{-1}$} & Mg ha-1 \\
\hline & & & \multicolumn{5}{|c|}{ Total organic C } \\
\hline Native grassland ${ }^{3}$ & & & 24.6 & 18.0 & 13.2 & 11.6 & 44.7 \\
\hline \multirow[t]{4}{*}{ CT } & $\mathrm{O} / \mathrm{M}$ & 0 & $9.6 \mathrm{Ba}^{4}$ & $8.6 \mathrm{Ba}$ & $8.8 \mathrm{NSb}$ & $8.6 \mathrm{Ab}$ & $27.8 \mathrm{Bb}$ \\
\hline & & 180 & $10.2 \mathrm{Ba}$ & $9.7 \mathrm{Ba}$ & $9.2 \mathrm{~b}$ & 9.4 Aa & $29.9 \mathrm{Bb}$ \\
\hline & OV/MC & 0 & $11.9 \mathrm{Ba}$ & $10.7 \mathrm{Ba}$ & $10.5 \mathrm{a}$ & $9.9 \mathrm{Aa}$ & $32.8 \mathrm{Ba}$ \\
\hline & & 180 & $12.8 \mathrm{Ba}$ & $11.3 \mathrm{Ba}$ & $10.5 a$ & $10.2 \mathrm{Aa}$ & $33.8 \mathrm{Ba}$ \\
\hline \multirow[t]{5}{*}{ NT } & O/M & 0 & $16.4 \mathrm{Ab}$ & $11.6 \mathrm{Ab}$ & $8.8 b$ & $8.4 \mathrm{Aa}$ & $31.2 \mathrm{Ab}$ \\
\hline & & 180 & $19.9 \mathrm{Ab}$ & $14.3 \mathrm{Ab}$ & $9.6 \mathrm{~b}$ & $8.1 \mathrm{Bb}$ & $33.6 \mathrm{Ab}$ \\
\hline & OV/MC & 0 & $22.2 \mathrm{Aa}$ & $15.9 \mathrm{Aa}$ & $10.7 \mathrm{a}$ & $9.1 \mathrm{Aa}$ & $37.4 \mathrm{Aa}$ \\
\hline & & 180 & $24.3 \mathrm{Aa}$ & $16.7 \mathrm{Aa}$ & $11.7 \mathrm{a}$ & $9.2 \mathrm{Ba}$ & $39.5 \mathrm{Aa}$ \\
\hline & & & \multicolumn{5}{|c|}{ Light fraction $\mathrm{C}$} \\
\hline Native grassland ${ }^{3}$ & & & 1.65 & 0.53 & 0.62 & 0.38 & 1.92 \\
\hline \multirow[t]{4}{*}{$\overline{\mathrm{CT}}$} & O/M & 0 & $0.50 \mathrm{Ba}$ & $0.35 \mathrm{NSns}$ & $0.30 \mathrm{NSb}$ & $0.31 \mathrm{NSns}$ & $1.06 \mathrm{Bb}$ \\
\hline & & 180 & $0.82 \mathrm{Ba}$ & 0.48 & $0.43 b$ & 0.40 & $1.47 \mathrm{Bb}$ \\
\hline & OV/MC & 0 & $1.02 \mathrm{Ba}$ & 0.40 & $0.32 a$ & 0.38 & $1.40 \mathrm{Ba}$ \\
\hline & & 180 & $1.34 \mathrm{Ba}$ & 0.70 & $0.51 \mathrm{a}$ & 0.48 & $1.92 \mathrm{Ba}$ \\
\hline \multirow[t]{4}{*}{ NT } & O/M & 0 & $1.28 \mathrm{Ab}$ & 0.88 & $0.35 b$ & 0.25 & $1.49 \mathrm{Ab}$ \\
\hline & & 180 & $2.43 \mathrm{Ab}$ & 0.80 & $0.38 b$ & 0.29 & $1.97 \mathrm{Ab}$ \\
\hline & OV/MC & 0 & $3.31 \mathrm{Aa}$ & 1.00 & $0.43 a$ & 0.27 & $2.38 \mathrm{Aa}$ \\
\hline & & 180 & $3.86 \mathrm{Aa}$ & 1.32 & $0.56 \mathrm{a}$ & 0.33 & $2.91 \mathrm{Aa}$ \\
\hline
\end{tabular}

${ }^{1} \mathrm{CT}=$ conventional tillage, $\mathrm{NT}=$ no-tillage; ${ }^{2} \mathrm{O} / \mathrm{M}=$ oats/maize; OV/MC = oats + vetch/maize + cowpea; ${ }^{3}$ Data from Lovato et al. (2004); ${ }^{4}$ Uppercase letters in each column compare tillage systems with the same cropping system and $\mathrm{N}$ rate, whereas lowercase letters compare cropping systems with the same tillage system and $\mathrm{N}$ rate, all by the Tukey test at $p<0.05$.

Table 4 - Carbon pool index (CPI), lability (L), C lability index (CLI) and C management index (CMI) in 0-20 cm layer and the stratification ratios for total organic C (SR-TOC) and the light fraction of organic matter (SR-LF) between 0-5 and 5-20 cm layers of a subtropical Acrisol subjected to two tillage systems, two cropping systems and two $\mathrm{N}$ fertilization rates for 18 years. Native grassland was used as reference of the original soil conditions.

\begin{tabular}{|c|c|c|c|c|c|c|c|c|}
\hline \multirow{2}{*}{ Soil tillage ${ }^{1}$} & \multirow{2}{*}{$\begin{array}{l}\text { Cropping } \\
\text { system }^{2}\end{array}$} & \multirow{2}{*}{$\mathrm{N}$ rate } & \multirow{2}{*}{ CPI } & \multirow{2}{*}{ L } & \multirow{2}{*}{$\mathrm{CLI}$} & \multirow{2}{*}{$\mathrm{CMl}$} & \multicolumn{2}{|c|}{ Stratification ratio $(0-5: 5-20 \mathrm{~cm})$} \\
\hline & & & & & & & Total organic C & Light fraction $\mathrm{C}$ \\
\hline & & $\mathrm{kg} \mathrm{ha}^{-1}$ & & & & & & \\
\hline \multicolumn{2}{|c|}{ Native grassland } & & 1.00 & 0.045 & 1.00 & 100 & 1.76 & 2.37 \\
\hline \multirow[t]{4}{*}{$\overline{\mathrm{CT}}$} & $\mathrm{O} / \mathrm{M}$ & 0 & $0.62 \mathrm{Bb}^{\star 3}$ & $0.040 \mathrm{Bb}^{*}$ & $0.89 A b^{*}$ & $55 \mathrm{Bb}^{*}$ & $1.05 \mathrm{Ba}^{\text {ns }}$ & $1.39 \mathrm{Bb}^{\text {ns }}$ \\
\hline & & 180 & $0.67 \mathrm{Bb}$ & $0.052 \mathrm{Bb}$ & $1.16 \mathrm{Ab}$ & $78 \mathrm{Bb}$ & $1.07 \mathrm{Ba}$ & 1.59 Ba \\
\hline & $\mathrm{OV} / \mathrm{MC}$ & 0 & $0.73 \mathrm{Ba}^{*}$ & $0.045 \mathrm{Ba}^{*}$ & $1.00 \mathrm{Aa}^{*}$ & $73 \mathrm{Ba}^{*}$ & $1.12 \mathrm{Ba}^{\text {ns }}$ & $1.97 \mathrm{Ba}^{\text {ns }}$ \\
\hline & & 180 & $0.76 \mathrm{Ba}$ & $0.062 \mathrm{Ba}$ & $1.37 \mathrm{Aa}$ & $104 \mathrm{Ba}$ & $1.17 \mathrm{Ba}$ & $2.08 \mathrm{Ba}$ \\
\hline \multirow[t]{4}{*}{ NT } & O/M & 0 & $0.70 A b^{*}$ & $0.050 \mathrm{Ab}^{*}$ & $1.11 \mathrm{Ab}^{*}$ & $78 \mathrm{Ab}^{*}$ & $1.64 A b^{*}$ & $3.81 \mathrm{Ab}^{*}$ \\
\hline & & 180 & $0.75 \mathrm{Ab}$ & $0.062 \mathrm{Ab}$ & $1.37 \mathrm{Ab}$ & $103 \mathrm{Ab}$ & $1.99 \mathrm{Aa}$ & $5.05 \mathrm{Ab}$ \\
\hline & $\mathrm{OV} / \mathrm{MC}$ & 0 & $0.84 \mathrm{Aa}^{*}$ & $0.068 \mathrm{Aa}^{*}$ & $1.51 \mathrm{Aa}^{*}$ & $127 \mathrm{Aa}^{*}$ & $1.98 \mathrm{Aa}^{\mathrm{ns}}$ & $6.66 \mathrm{Aa}^{\mathrm{ns}}$ \\
\hline & & 180 & $0.88 \mathrm{Aa}$ & $0.080 \mathrm{Aa}$ & $1.78 \mathrm{Aa}$ & $157 \mathrm{Aa}$ & $2.04 \mathrm{Aa}$ & $6.37 \mathrm{Aa}$ \\
\hline
\end{tabular}

${ }^{1} \mathrm{CT}=$ conventional tillage; $\mathrm{NT}=$ no-tillage. ${ }^{2} \mathrm{O} / \mathrm{M}=$ oats/maize; $\mathrm{OV} / \mathrm{MC}=$ oats + vetch /maize + cowpea. ${ }^{3}$ Uppercase letters in each column compare tillage systems with the same cropping system and $\mathrm{N}$ rate, whereas lowercase letters compare cropping systems with the same tillage system and $\mathrm{N}$ rate, all by the Tukey test at $p<0.05$. * show statistically significant differences between $\mathrm{N}$ fertilization treatments $\left(0\right.$ and $\left.180 \mathrm{~kg} \mathrm{ha}^{-1}\right)$ for the combination of soil tillage and cropping system.

oxidative environment and stabilization of SOM labile fractions in soil aggregates (Tivet et al., 2013).

Among the CMI components, CLI was more sensitive to differences in soil management than CPI was, which is consistent with the results of previous studies (De Bona et al., 2008; Diekow et al., 2005). In this work, NT increased CLI by a factor of 5 and CPI by a factor smaller than 2 (Figures 1A and B; Table 4). Therefore, besides the $\mathrm{C}$ stock and its importance in understanding management system effects on soil quality, the lability component of $\mathrm{CMI}$ increases ratio sensitivity in relation to soil organic $\mathrm{C}$ stocks alone. This is a result of rapid LF cycling in relation to total organic $\mathrm{C}$, where changes in $\mathrm{C}$ stocks of $\mathrm{LF}$, detected via CLI, are apparent in the short term (Diekow et al., 2005).

Similarly to previous studies (De Bona et al., 2008; Souza et al., 2014), the highest CMI values were observed under NT compared to CT. In fact, CMI was on 

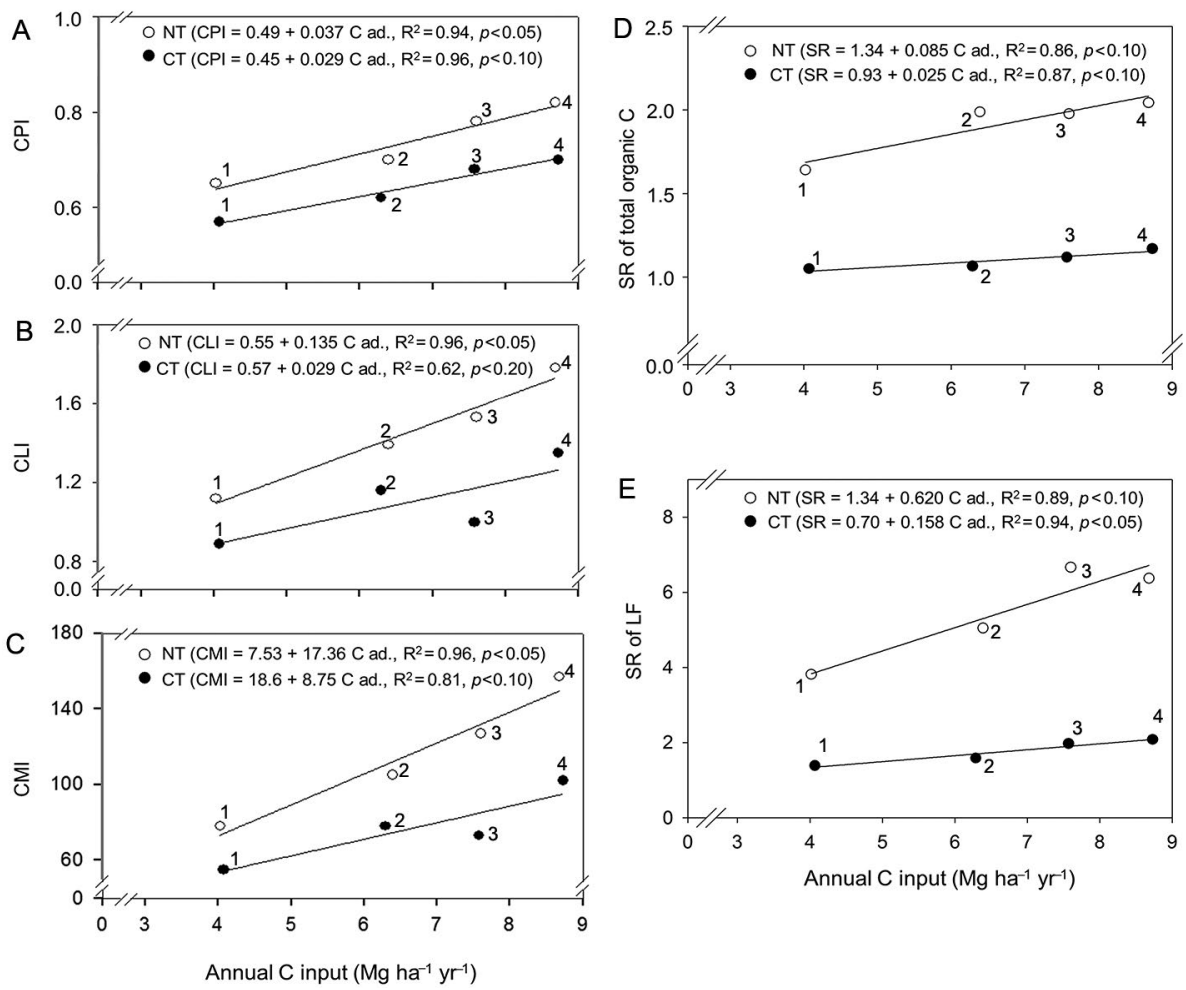

Figure 1 - Relationship between annual C input via the cropping systems and (A) Carbon Pool Index (CPI), (B) Carbon Lability Index (CLI), (C) Carbon Management Index (CMI), (D) Stratification Ratio for Total Organic C (SR-TOC), and (E) for the light fraction of organic matter (SR-LF) in 0-0.2 m layer of a subtropical Acrisol subjected to two tillage systems (CT = conventional tillage; NT = no-tillage), two cropping systems (oat/ maize and oat+vetch/maize+cowpea) and two $\mathrm{N}$ rates to maize ( 0 and $180 \mathrm{~kg}$ ha-1) for 18 years.

average $50 \%$ higher under NT than under CT. In addition, differences between cropping systems and $\mathrm{N}$ fertilizer rates were due to treatments on biomass supply by crop residues (Table 4, Figure 1C). Adopting tillage systems that cease soil disturbance and using legume cover crops in succession with maize for 18 years led to increased CMI values compared to the control (native grassland), due to better soil quality (Table 4). On the other hand, CMI in the system with constant soil disturbance and little addition of plant residues (CT O/M ON) was $45 \%$ lower than in the native grassland, suggesting that these systems hinder soil quality with a high potential for degradation.

Conservation tillage also increased CMI in relation to native vegetation in previous studies using the index to assess soil quality (Diekow et al., 2005; Souza et al., 2014). Therefore, this study suggest that NT facilitates conservation of soil quality and restoration of degraded soils in subtropical and tropical regions. However, maximizing soil quality also entails intensive farming and supplying amounts of residues greater than $10 \mathrm{Mg} \mathrm{DM} \mathrm{ha}^{-1}$ each year (Lovato et al., 2004; Sá et al., 2015). Moreover, CMI may be used as a sensitive indicator of changes caused by management practices in subtropical soils and extraction of labile $\mathrm{C}$ to calculate $\mathrm{C}$ lability can be efficiently accomplished by density fractionation of SOM.

\section{Carbon stratification ratio}

The increased $\mathrm{C}$ content in the whole soil and LF of the soil surface under NT in relation to CT reflected in increased SR-TOC and SR-LF values (Table 4). SR-TOC ranged from 1.05 to 2.04 and was on average 1.10 under CT and 1.91 under NT. These values are consistent with those of other studies involving different climate and soil types (Ferreira et al., 2013; Figueiredo et al., 2013; Franzluebbers, 2002; Sá and Lal, 2009).

Previous studies have also shown that, in general, SR-TOC decreases from soils in temperate regions to soils in a tropical climate. Thus, according to Franzluebbers (2002), SR values above 2.0 for temperate soils indicate high soil quality, because this level is uncommon for degraded soils. However, Ferreira et al. (2013) noted that values greater than 1.5 to 1.7 indicate high quality in subtropical soils (e.g. Oxisols and Alfisols). Decreased SR values for soils under tropical or subtropical climate, in relation to a temperate climate, may have various origins but are probably the primary result of the highly efficient colloidal protection of SOM by oxides helping to keep relatively high $\mathrm{C}$ contents in sub-surface layers of oxidic soils compared to temperate soils (Bayer et al., 2001).

In our study, all treatments under NT had SR-TOC values above 1.6, whereas values under CT never ex- 
ceeded 1.2 (Table 4). The high SR-TOC values under NT, which even exceeded those of native grassland, resulted from the addition and maintenance of crop residues on the soil surface, creating a steady stream of $\mathrm{C}$ in the soil surface (Sá and Lal, 2009). C accumulation in surface layers has a positive effect on crop production and soil conservation through improved physical, chemical and biological soil conditions (Franzluebbers, 2002; Franzluebbers, 2010; Sá and Lal, 2009). Thus, increased SRTOC values under NT indicate that this management system improves soil properties and environmental quality in the long term.

SR-LF was higher under NT (5.47) than under CT (1.76) regardless of the particular crop and N-fertilizer rate (Table 4). This result indicates a 3.12-fold increase in SR-LF by adopting a NT system. Therefore, this index is more sensitive than SR-TOC as an indicator of changes caused by management, which was only 1.74 greater under NT compared to CT. An increased sensitivity of SR to the labile compartments, such as microbial biomass $\mathrm{C}$ (Franzluebbers, 2002), particulate nitrogen (Sá and Lal, 2009) and particulate organic carbon (Figueiredo et al., 2013), has been observed in a wide range of soil and climate types. Therefore, SR-LF is a better indicator than SR-TOC to assess soil quality for a management system. The high SR-LF value under NT obtained in this work indicates that this management system provides effective protection for labile SOM compartments, thereby resulting in improved soil quality by maintaining aggregation and soil protection through crop residues.

In addition to the soil management system, SR$\mathrm{LF}$ was also more sensitive for cropping systems. The legume-based system (i.e. OV/MC) had a higher SR-LF value than the grass-based system (i.e. O/M) under both NT and CT, which was not the case with SR-TOC (Table 4). As shown by the close, positive relationship of $C$ addition through crop residues with SR-TOC and SR-LF under both NT and CT (Figures 1A-E), the increased SR$\mathrm{LF}$ value in the OV/MC system can be ascribed to increased residue production by this cropping system. In addition, SR-TOC in OV/MC under NT was close to 2.0 (1.98 and 2.04 for 0 and $180 \mathrm{~kg} \mathrm{~N} \mathrm{ha}^{-1}$, respectively), the soil quality reference proposed by Franzluebbers (2002). This result again suggests that long-term application of NT (18 years) in combination with a rotation of diverse crops, including legumes, can help ensure agricultural sustainability in subtropical environments.

\section{Relationship of CMI and SR with soil quality indicators and maize yield}

Table 5 illustrates that, in general, $\mathrm{C}$ indices (CMI, SR-TOC and SR-LF) were positively correlated with physical [aggregate stability (AS)], chemical [cation exchange capacity (CEC)] and biological [microbial biomass (C-MBC) soil quality indicators, as well as indicators of carbon dioxide evolution $\left(\mathrm{C}-\mathrm{CO}_{2}\right)$ and potentially mineralizable nitrogen (PMN)]. The most significant relationships included SR-LF ( $p<0.05$ for all attributes).
Table 5 - Relationship between soil $\mathrm{C}$ indices $(\mathrm{CMl}=$ carbon management index; SR-TOC = stratification ratio for total organic C; SR-LF = stratification ratio for light fraction of organic matter) and biological $\left(\mathrm{C}-\mathrm{MBC}=\right.$ microbial biomass; $\mathrm{C}-\mathrm{CO}_{2}=$ carbon dioxide evolution; and PMN = potentially mineralizable nitrogen), physical (AS = aggregate stability) and chemical (CEC = cation exchange capacity) soil quality indicators.

\begin{tabular}{|c|c|c|c|c|}
\hline Soil property & Intercept & Slope & $\mathrm{R}^{2}$ & $p$ \\
\hline & \multicolumn{4}{|c|}{$\mathrm{CMl}$} \\
\hline C-MBC & 46.25 & 1.30 & 0.88 & 0.063 \\
\hline $\mathrm{C}-\mathrm{CO}_{2}$ & -31.06 & 2.40 & 0.87 & 0.069 \\
\hline PMN & -1.52 & 0.14 & 0.99 & 0.002 \\
\hline AS & 37.28 & 0.36 & 0.77 & 0.122 \\
\hline \multirow[t]{2}{*}{ CEC } & 9.64 & 0.008 & 0.46 & 0.065 \\
\hline & \multicolumn{4}{|c|}{ SR of total organic $C$} \\
\hline C-MBC & 8.00 & 107.84 & 0.97 & 0.016 \\
\hline $\mathrm{C}-\mathrm{CO}_{2}$ & -102.52 & 199.77 & 0.96 & 0.019 \\
\hline PMN & -2.96 & 10.03 & 0.79 & 0.111 \\
\hline AS & 24.14 & 31.45 & 0.95 & 0.026 \\
\hline \multirow[t]{2}{*}{ CEC } & 9.16 & 0.85 & 0.87 & $<0.001$ \\
\hline & \multicolumn{4}{|c|}{ SR of LF } \\
\hline C-MBC & 86.54 & 24.25 & 0.99 & 0.001 \\
\hline $\mathrm{C}-\mathrm{CO}_{2}$ & 43.80 & 44.68 & 0.98 & 0.009 \\
\hline PMN & 3.91 & 2.38 & 0.90 & 0.050 \\
\hline AS & 47.75 & 6.88 & 0.92 & 0.039 \\
\hline CEC & 9.80 & 0.18 & 0.89 & $<0.001$ \\
\hline
\end{tabular}

Positive relationships of CMI and SR-TOC with physical, chemical and biological soil properties have been previously reported (Franzluebbers, 2002; Sá and Lal, 2009; Vieira et al., 2007). Moreover, the close relationship of these $\mathrm{C}$ indices with physical, chemical and biological soil properties confirms their usefulness as soil quality indicators, as well as their high sensitivity to soil changes due to management systems.

Few studies have examined the relationship of CMI, SR-TOC and SR-LF with crop yield (Ghosh et al., 2016; Vieira et al., 2007). In this work, we found a poor relationship $(p>0.17)$ between soil $\mathrm{C}$ indices and maize yield (average of five crop seasons, 2001-2005) (Table 6). The poor relationship of the $\mathrm{C}$ indices with maize yield showed that the improved soil quality also revealed by better soil physical, chemical and biological parameters did not reflect in higher maize yields. Although soil quality based on $\mathrm{C}$ indices represents soil structure improvements and hence increased water retention (Denef et al., 2004) and improved biological activity, which control nutrient cycling and mineralization (Alvarez et al., 1998), some agricultural practices, like $\mathrm{N}$ fertilization $(180 \mathrm{~N})$ and irrigation, have possibly masked the potential benefits of improved soil quality on maize yield.

\section{Conclusion}

All indices used in this study (e.g. CMI, SR-TOC and SR-LF) were sensitive indicators to assess quality of soil management systems and were strongly related 
Table 6 - Relationship between soil $\mathrm{C}$ indices $(\mathrm{CMI}=$ carbon management index; SR-TOC = stratification ratio for total organic C; SR-LF = stratification ratio for light fraction of organic matter) and maize yield in a subtropical Acrisol subjected to different management systems for 18 years.

\begin{tabular}{lcrrrr}
\hline \multirow{2}{*}{ Soil tillage ${ }^{1}$} & \multirow{2}{*}{ C index } & \multicolumn{4}{c}{ Maize yield } \\
\cline { 3 - 6 } & & Intercept & Slope & \multicolumn{1}{c}{$\mathrm{R}^{2}$} & \multicolumn{1}{c}{$p$} \\
\hline CT & CMl & -4.70 & 0.14 & 0.68 & 0.174 \\
& SR for total C & -26.33 & 29.41 & 0.22 & 0.536 \\
& SR for LF & -10.68 & 4.07 & 0.14 & 0.615 \\
\hline NT & CMl & -1.97 & 0.07 & 0.45 & 0.329 \\
& SR for total C & -24.63 & 16.24 & 0.67 & 0.180 \\
& SR for LF & -0.63 & 1.29 & 0.22 & 0.535 \\
\hline
\end{tabular}

${ }^{1} \mathrm{CT}=$ conventional tillage; NT = no-tillage.

with physical, chemical and biological soil quality indicators. The most sensitive index was SR-LF, which exhibited the most significant relationship with soil quality indicators. Using these easily assessed and simple C indices rather than a large number of soil parameters may be suitable, less costly and very useful to address soil quality of management systems. C indices illustrate that the absence of soil disturbance (no-till) and an abundant supply of crop residues (legume-based cropping systems and $\mathrm{N}$ fertilization) are key strategies for effective conservation of soil functions and crop yields in humid subtropical environments.

\section{Acknowledgements}

This work was funded by the Conselho Nacional de Desenvolvimento Científico e Tecnológico (CNPq) and the Fundação de Amparo à pesquisa do Estado do Rio Grande do Sul (FAPERGS). The authors thank the staff at the Estação Experimental Agronômica of Universidade Federal do Rio Grande do Sul (UFRGS) who helped and supported all agricultural operations in the long-term experiment.

\section{Authors' Contributions}

Conceptualization: Zanatta, J.A.; Bayer, C. Data acquisition: Zanatta, J.A.; Bayer, C. Data analysis: Zanatta, J.A.; Vieira, F.C.B.; Briedis, C. Writing and editing: Zanatta, J.A.; Vieira, F.C.B.; Briedis, C.; Dieckow, J.; Bayer, C.

\section{References}

Alvarez, C.R.; Alvarez, R.; Grigera, M.S.; Lavado, R.S. 1998. Associations between organic matter fractions and the active soil microbial biomass. Soil Biology and Biochemistry 30: 767773.

Amado, T.J.C.; Conceição, P.C.; Bayer, C.; Eltz, F.L.F. 2007. Soil quality evaluated by "soil quality kit" in two long-term soil management experiments in Rio Grande do Sul state, Brazil. Revista Brasileira de Ciência do Solo 31: 109-121 (in Portuguese, with abstract in English).
Bayer, C.; Martin-Neto, L.; Mielniczuk, J.; Pillon, C.N.; Sangoi, L. 2001. Changes in soil organic matter fractions under subtropical no-till cropping systems. Soil Science Society of America Journal 65: 1473-1478.

Bayer, C.; Mielniczuk, J.; Amado, T.J.C.; Martin-Neto, L.; Fernandes, S.V. 2000. Organic matter storage in a sandy clay loam Acrisol affected by tillage and cropping systems in southern Brazil. Soil and Tillage Research 54: 101-109.

Blair, G.J.; Lefroy, R.D.B.; Lisle, L. 1995. Soil carbon fractions based on their degree of oxidation, and the development of a carbon management index for agricultural systems. Australian Journal of Agricultural Research 46: 1459-1466.

Boddey, R.M.; Jantalia, C.P.; Conceição, P.C.; Zanatta, J.A.; Bayer, C.; Mielniczuk, J.; Dieckow, J.; Santos, H.P.; Denardin, J.E.; Aita, C.; Giacomini, S.J.; Alves, B.J.R.; Urquiaga, S. 2010. Carbon accumulation at depth in Ferralsols under zero-till subtropical agriculture. Global Change Biology 16: 784-795.

Conceição, P.C.; Amado, T.J.C.; Mielniczuk, J.; Spagnollo, E. 2005. Soil organic matter and other attributes as indicators to evaluate soil quality in conservation systems. Revista Brasileira de Ciência do Solo 29: 777-788 (in Portuguese, with abstract in English).

Conceição, P.C.; Dieckow, J.; Bayer, C. 2013. Combined role of no-tillage and cropping systems in soil carbon stocks and stabilization. Soil and Tillage Research 129: 40-47.

De Bona, F.D.; Bayer, C.; Dieckow, J.; Bergamaschi, H. 2008. Soil quality assessed by carbon management index in a subtropical Acrisol subjected to tillage systems and irrigation. Soil Research 46: 469-475.

Denef, K.; Six, J.; Merckx, R.; Paustian, K. 2004. Carbon sequestration in microaggregates of no-tillage soils with different clay mineralogy. Soil Science Society of America Journal 68: 1935-1944.

Diekow, J.; Mielniczuk, J.; Knicker, H.; Bayer, C.; Dick, D.; KögelKnabner, I. 2005. Carbon and nitrogen stocks in physical fractions of a subtropical Acrisol as influenced by long-term no-till cropping systems and $\mathrm{N}$ fertilisation. Plant and Soil 268: 319-328.

Ellert, B.H.; Bettany, J.R. 1995. Calculation of organic matter and nutrients stored in soils under contrasting management regimes. Canadian Journal of Soil Science 75: 529-538.

Ferreira, A.O.; Amado, T.J.C.; Nicoloso, R.S.; Sá, J.C.M.; Fiorin, J.E.; Hansel, D.S.S.; Menefee, D. 2013. Soil carbon stratification affected by long-term tillage and cropping systems in southern Brazil. Soil and Tillage Research 133: 65-74.

Figueiredo, C.C.; Resck, D.V.S.; Carneiro, M.A.C.; Ramos, M.L.G.; Sá, J.C.M. 2013. Stratification ratio of organic matter pools influenced by management systems in a weathered Oxisol from a tropical agro-ecoregion in Brazil. Soil Research 51: 133-141.

Franzluebbers, A.J. 2002. Soil organic matter stratification ratio as an indicator of soil quality. Soil and Tillage Research 66: 95-106.

Franzluebbers, A.J. 2010. Achieving soil organic carbon sequestration with conservation agricultural systems in the southeastern United States. Soil Science Society of America Journal 74: 347-357. 
Gerland, P.; Raftery, A.E.; Ševčíková, H.; Li, N.; Gu, D.; Spoorenberg, T.; Alkema, L.; Fosdick, B.K.; Chunn, J.; Lalic, N.; Bay, G.; Buettner, T.; Heilig, G.K.; Wilmoth, J. 2014. World population stabilization unlikely this century. Science 346: 234237.

Ghosh, B.N.; Meena, V.S.; Alam, N.M.; Dogra, P.; Bhattacharyya, R.; Sharma, N.K.; Mishra, P.K. 2016. Impact of conservation practices on soil aggregation and the carbon management index after seven years of maize-wheat cropping system in the Indian Himalayas. Agriculture, Ecosystems \& Environment 216: 247-257.

Houghton, R.A. 2014. The Contemporary carbon cycle. p. 399435. In: Turekian, H.D.H.K., ed. Treatise on geochemistry. Elsevier, Oxford, UK.

Lal, R. 2004. Soil carbon sequestration impacts on global climate change and food security. Science 304: 1623-1627.

Lovato, T.; Mielniczuk, J.; Bayer, C.; Vezzani, F. 2004. Carbon and nitrogen addition related to stocks of these elements in soil and corn yield under management systems. Revista Brasileira de Ciência do Solo 28: 175-187 (in Portuguese, with abstract in English).

Qiu, Q.; Wu, L.; Ouyang, Z.; Li, B.; Xu, Y.; Wu, S.; Gregorich, E.G. 2016. Priming effect of maize residue and urea $\mathrm{N}$ on soil organic matter changes with time. Applied Soil Ecology 100: 65-74.

Sá, J.C.M.; Lal, R. 2009. Stratification ratio of soil organic matter pools as an indicator of carbon sequestration in a tillage chronosequence on a brazilian Oxisol. Soil and Tillage Research 103: 46-56.
Sá, J.C.M.; Séguy, L.; Tivet, F.; Lal, R.; Bouzinac, S.; Borszowskei, P.R.; Briedis, C.; Santos, J.B.; Hartman, D.C.; Bertoloni, C.G.; Rosa, J.; Friedrich, T. 2015. Carbon depletion by plowing and its restoration by no-till cropping systems in oxisols of subtropical and tropical Agro-Ecoregions in Brazil. Land Degradation and Development 26: 531-543.

Silva, M.A.S.; Mafra, Á.L.; Albuquerque, J.A.; Bayer, C.; Mielniczuk, J. 2005. Soil physics properties related to water storage and tillage systems in a Loamy Acrisol. Ciência Rural 35: 544-552 (in Portuguese, with abstract in English).

Souza, E.D.; Costa, S.E.V.G.A.; Anghinoni, I.; Carneiro, M.A.C.; Martins, A.P.; Bayer, C. 2014. Soil quality indicators in a Rhodic Paleudult under long term tillage systems. Soil and Tillage Research 139: 28-36.

Tivet, F.; Sá, J.C.M.; Lal, R.; Briedis, C.; Borszowskei, P.R.; Santos, J.B.; Farias, A.; Eurich, G.; Hartman, D.C.; Nadolny Junior, M.; Bouzinac, S.; Séguy, L. 2013. Aggregate C depletion by plowing and its restoration by diverse biomass-C inputs under no-till in sub-tropical and tropical regions of Brazil. Soil and Tillage Research 126: 203-218.

Vieira, F.C.B.; Bayer, C.; Zanatta, J.A.; Dieckow, J.; Mielniczuk, J.; He, Z.L. 2007. Carbon management index based on physical fractionation of soil organic matter in an Acrisol under longterm no-till cropping systems. Soil and Tillage Research 96: 195-204.

Zanatta, J.A.; Bayer, C.; Dieckow, J.; Vieira, F.C.B.; Mielniczuk, J. 2007. Soil organic carbon accumulation and carbon costs related to tillage, cropping systems and nitrogen fertilization in a subtropical Acrisol. Soil and Tillage Research 94: 510-519. 